\title{
Molars extraction for bone graft study in rabbits $^{1}$
}

\author{
Extração de molares para estudos de enxertos ósseos em coelhos
}

\author{
José Eduardo Ferreira Manso', Carlos Fernando de Almeida Barros MourãoII, Flávio Alexandre Lima Pinheiro ${ }^{\text {III }}$, Manoel Luiz \\ Ferreira $^{I V}$, Paulo César Silva ${ }^{\mathrm{v}}$, Alberto Schanaider ${ }^{\mathrm{VI}}$

\begin{abstract}
IAssociate Professor, Postgraduate Program in Surgical Sciences, UFRJ, Rio de Janeiro, Brazil. Supervised all phases of the study.
IFellow Master degree, Postgraduate Program in Surgical Sciences, UFRJ, Rio de Janeiro, Brazil. Designed the protocol, involved with technical procedures, responsible for manuscript writing.

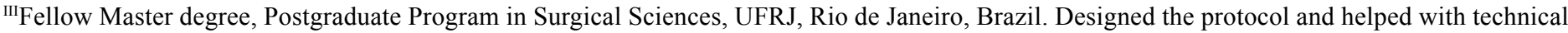
procedures.

${ }^{\mathrm{V}}$ Fellow PhD degree, Postgraduate Program in Surgical Sciences, UFRJ, Rio de Janeiro, Brazil. Provided guidelines for the surgical interventions.

${ }^{v}$ Associate Professor, UFRJ, Rio de Janeiro, Brazil. Supervised all phases of the study.
\end{abstract} \\ ${ }^{\mathrm{VI}}$ Chairman, Full Professor, Postgraduate Program in Surgical Sciences, UFRJ, Rio de Janeiro, Brazil. Critical revision.
}

\begin{abstract}
PURPOSE: The aim of this study was to describe an experimental surgical technique to be used in the evaluation of bone grafts in rabbits.

METHODS: The operative technique was performed in jaws, with external approach from the labial commissure to the last molar tooth. An incision about $1 \mathrm{~cm}$ extended forward to the alveolar ridge, followed by a exposing the cervical region of the alveolar bone and dental elements was done. Thus, after extraction of first molar with forceps, the tooth socket left was filled with hydroxyapatite. The bone gain was analyzed by histopathological studies.

RESULTS: The histological analyses indicated formed bone surrounding the biomaterial.

CONCLUSION: The experimental model using the tooth socket of the rabbit molar is a feasible procedure for studies of bone grafts. Key words: Animal Experimentation. Dental Models. Rabbits.
\end{abstract}

\section{RESUMO}

OBJETIVO: Descrever uma técnica cirúrgica em coelhos para avaliação de enxertos ósseos.

MÉTODOS: A técnica operatória consiste numa incisão na topografia da comissura labial até o ultimo molar. Uma incisão de $1 \mathrm{~cm}$ no rebordo para expor o osso alveolar e a região cervical dos molares. Realizou-se a exodontia com fórceps e o alvéolo é preenchido com hidroxiapatita. Após o tempo de cicatrização é realizada a avaliação histológica.

RESULTADOS: A análise histológica mostrou o novo osso formado rodeando biomaterial.

CONCLUSÃO: O modelo cirúrgico para avaliação de enxertos ósseos utilizando molares de coelhos se mostrou factível.

Descritores: Experimentação Animal. Modelos Dentários. Coelhos.

\section{Introduction}

The alveolar bone is modified both in quality and in quantity after tooth extraction ${ }^{1}$. The healing process results in a formation of trabecular bone and marrow due significant bone loss, mainly on the walls and inside buccal and lingual/ palatine regions ${ }^{2}$.

Various materials are used to prevent such bone loss after tooth extraction, for example: dental implants, physical barriers ${ }^{3}$, and/ or bone grafts ${ }^{4}$.
A variety of bone grafts have been used in maxillofacial surgery. Although a wide variety of bone grafts and implants have been evaluated in various species of experimental animals, there has been little consistency among investigators in the choice of an appropriate animal model ${ }^{5-7}$. Some researchers are already using tooth socket as a model including the use of dog, rat and rabbit incisors for these studies ${ }^{8-12}$.

The authors describe a new experimental surgical technique using the tooth socket of the rabbit molar useful in the evaluation of bone grafts. 


\section{Methods}

This study was approved by the Ethics Committee for Use of Laboratory Animals in Research of the Faculty of Medicine of UFRJ, Protocol 076/09.

Pre and postoperatively, the animals were kept in individual cages in a temperature-controlled environment with water ad libitum and standardized feed.

For the development of the surgical procedure were used six rabbits (Oryctolagus cuniculus) New Zealand, white, male, weighing $2.5 \mathrm{~kg}$ to $3.0 \mathrm{~kg}$ with a mean age of ten months, operated and maintained in the Center of Experimental Surgery, School of Medicine, UFRJ.

We used intravenous general anesthesia with the combination of benzodiazepines $(5 \mathrm{mg} / \mathrm{kg})$ and $10 \%$ ketamine $(25 \mathrm{mg} / \mathrm{kg})$. The rabbits were anesthetized with lidocaine $1 \%$, the maximum dose of $9 \mathrm{mg} / \mathrm{Kg}$, with infiltration trunk to block the inferior alveolar and the labial commissure.

The surgery was performed in the jaw with an external approach incision, from the labial commissure to the last molar tooth, by about $1 \mathrm{~cm}$ in length (Figure 1), prior to the alveolar ridge. Then the cervical region of the teeth was exposed, as well as the alveolar bone (Figure 2). Thus, after extraction of first molar with forceps, a bone store average of $3 \mathrm{~mm}$ (mesio-distal) X $3 \mathrm{~mm}$ (buccolingual) X $12 \mathrm{~mm}$ (cervical-apical) was found, with the average size of the walls buccal, lingual, and mesial distal with approximately $1.5 \mathrm{~mm}$ (Figure 3). Subsequently, the bone graft (biomaterial) was placed in the tooth socket with a Molt surgical curette. In the present work the material chosen for the graft were beads of hydroxyapatite (HA) (Figure 4). The wound closure was done in layers with sutures of the mucosa, muscle and subcutaneous tissue with polyglycolic acid 4-0 and the skin with 4-0 monofilament nylon.

Postoperative analgesia was performed using intramuscular ketoprofen at a dose of $1 \mathrm{mg} / \mathrm{kg}$ every 24 hours, and enrofloxacin at a dose of $10 \mathrm{mg}$ once daily for five days.

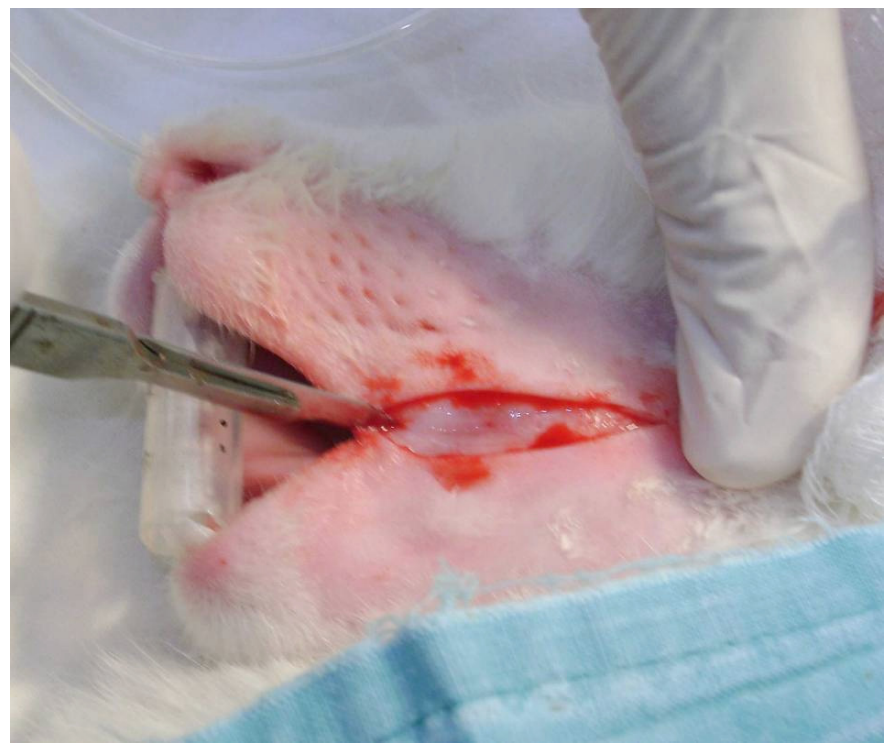

FIGURE 1 - Extraoral approach.with the skin incision.

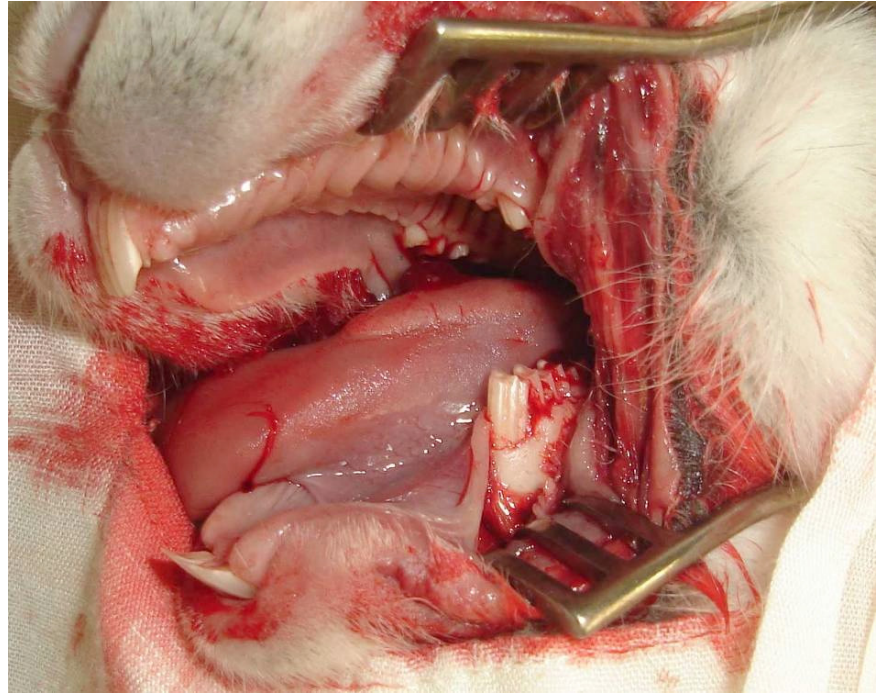

FIGURE 2 - Exposure of the cervical region of teeth and alveolar bone.

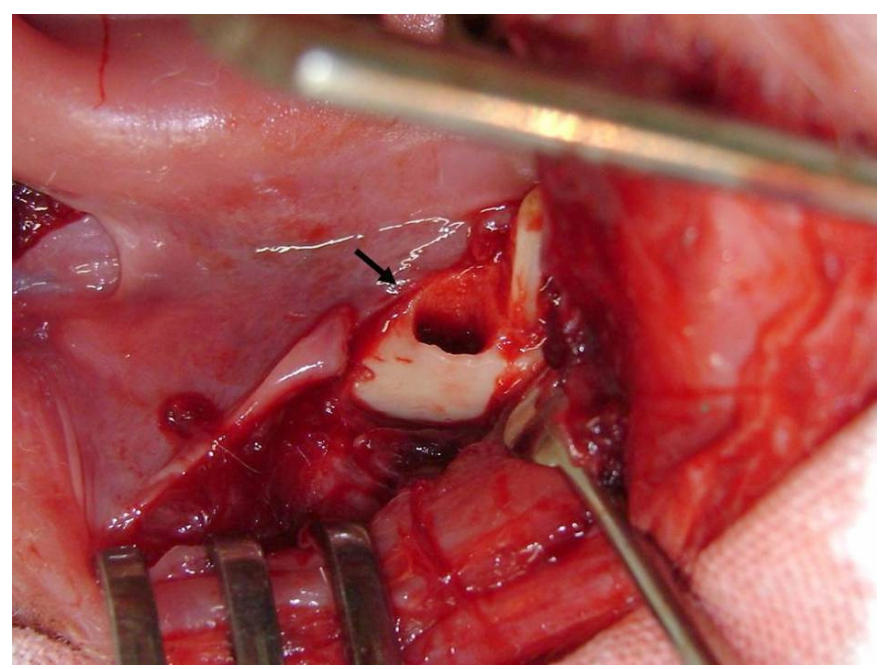

FIGURE 3 - Tooth socket of the first molar.

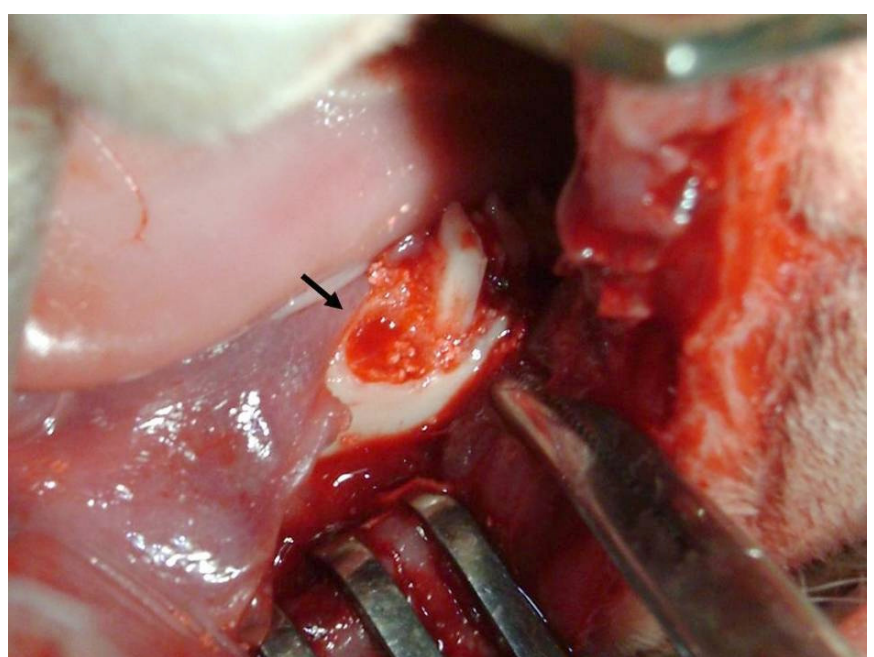

FIGURE 4 - Implantation of the bone graft in the tooth socket. 


\section{Results}

The former histological results showed a fibrous connective tissue surrounding the biomaterial (HA) and a new bone formation, sparse inflammatory infiltrate with few multinucleated giant cells.

In all animals, during the tooth extraction there was no root fracture and it was feasible a primary wound closure. It was also not observed wound dehiscence, infection or loss of grafting material.

\section{Discussion}

Relevant researches have been undertaken with the aim of discussing the use of more appropriate materials for effective repair of bone lesions in surgical animal model. One of the most known surgical models is the critical bone defect, which means to make bone impairment with the smallest dimensions that cannot be repaired spontaneously during the lifetime of the animal ${ }^{9}$. However, as most studies have limited duration it should be considered as a critical repair of bone defects that do not suffer during the research ${ }^{13}$. The healing of the alveoli is a well known biological event and cannot be considered as a critical defect in experimental studies.

Schmitz and Holliger ${ }^{6}$, in their experiments, described some models of bone lesions in different sites such as the calvaria and mandible without reporting the changes in the jaw bone of rabbits ${ }^{9}$. Bone defects caused in the region of the mandible body $15 \mathrm{x} 10 \mathrm{~mm}$ in rabbits were used for studies of bone grafts with the aid of fixing ${ }^{10,14}$. A surgical model with a bone store was proposed to be used to evaluate bone graft without fixation and protection using the alveoli of the molars of the rabbit.

Other researchers have used the rabbit incisor for their studies of biomaterials. However, this roots have large curvature and hampers their extraction ${ }^{9,10}$. The use of extra-oral access decrease the surgical difficulty and the biomaterial can be used up at four teeth sockets with similar proportions in the same animal and resulting in less amount of animals required.

The dental alveolus is ideal for bone formation after a tooth extraction, since all the relevant factors are present to maintain immobilization and graft ${ }^{15}$. The surgical technique presented in our study, molar extraction was feasible to manufacture a bone store compatible with the same favorable factors described by Becker.

During embryonic development, the jaw bone is the second to be formed, whose origin is from the first gill arch, with a background different from the other bones of the body ${ }^{16}$. The fact of using bone grafts, allografts, xenografts and alloplastic several bones as the tibia, femur and calvaria ${ }^{2,8-11,17-19}$ away from the area of work in dentistry, which is why the choice of jaw for use in a model for application of biomaterials.

The tooth socket of dogs are also used for these studies ${ }^{2,11}$. However, this surgical model in rabbits has offered advantages over the cost, space, storage and maintenance ${ }^{5}$.

\section{Conclusion}

Tooth socket of the molar of the rabbit seems to be a reliable and a feasible surgical procedure to study bone grafts.

\section{References}

1. Amler MH, Johnson PL, Salsman I. Histologic and histochemical investigation of human alveolar socket healing in undisturbed extraction wounds. J Am Dent Assoc. 1960;61:46-8.

2. Cardaropoli G, Araujo M, Lindhe J. Dynamic of bone tissue formation in tooth extraction sites. An experimental study in dogs. J Clin Periodontol. 2003;30:809-18

3. Mellonig JP, Triplett RG. Guided tissue regeneration and endosseous dental implants. Int J Periodontics Restorative Dent. 1993;13:109-19.

4. Becker W, Cameron C, Sennerby L, Urist M, Becker B. Histologic findings after implantation and evaluation of different grafting materials and titanium micro screws into extraction sockets: case reports. J Periodontol. 1998;69:414-21.

5. Schanaider A, Silva PC. Uso de animais em cirurgia experimental. Acta Cir Bras. 2004;19:441-7.

6. Schmitz JP, Holinger JO. The critical size defect as an experimental model for craniomandibulofacial nonunions. Clin Orthop Relat Res.1986;205:299-308.

7. Rabie AB, Deng YM, Samman N, Hagg U. The effect of demineralized bone matrix on the healing of intramembranous bone grafts in rabbit skull defects. J Dent Res. 1996;75:1045-51.

8. Fisher JP, Lalani Z, Bossano CM, Brey EM, Demian N, Johnston CM, Dean D, Jansen JA, Wong ME, Mikos AG. Effect of biomaterial properties on bone healing in a rabbit tooth extraction socket model. J Biomed Mater Res A. 2004;68:428-38.

9. Lalani Z, Wong M, Brey EM, Mikos AG, Duke PJ, Miller MJ, Johnston C, Montufar-Solis D. Spatial and temporal localization of FGF-2 and VEGF in healing tooth extraction sockets in a rabbit model. J Oral Maxillofac Surg. 2005;63:1500-8.

10. Marei MK, Nouh SR, Saad MM, Ismail NS. Preservation and regeneration of alveolar bone by tissue-engineered implants. Tissue Eng. 2005;11:751-67.

11. Araújo M, Linder E, Wennström J, Lindhe J. The influence of BioOss Collagen on healing of an extraction socket: an experimental study in the dog. Int J Periodontics Restorative Dent. 2008;28:123-35.

12. Duailibi SE, Duailibi MT, Zhang W, Asrican R, Vacanti JP, Yelick PC. Bioengineered dental tissues grown in the rat jaw. J Dent Res. 2008;87:745-50.

13. Gosain AK, Song L, Yu P, Mehrara BJ, Maeda CY, Gold LI, Longaker MT. Osteogenesis in cranial defects: reassessment of the concept of critical size and the expression of TGF-beta isoforms. Plast Reconstr Surg. 2000;106:360-71.

14. Li Zhi, Li Zu-Bing Repair of mandible defect with tissue engineering bone in rabbits. ANZ J Surg. 2005;75:1017-21.

15. Becker W, Becker BE, Caffesse R. A comparison of demineralized freezer-dried bone and altologous bone to induce bone formation in human extraction sokets. J Peridontol. 1994;65:1028-33.

16. Wei H, Zili L, Yuanlu C, Biao Y, Cheng L, Xiaoxia W, Yang L, Xing W. Effect of icariin on bone formation during distraction osteogenesis in the rabbit mandible. Int J Oral Maxillofac Surg. 2011;40:413-8.

17. Costa OR, Weinstein FJ. Injertos osnos em regeneration periodontal. Rev Asoc Odontol Argent. 1994;82:117-25. 
18. Andersson L, Ramzi A, Joseph B. Studies on dentin grafts to bone defects in rabbit tibia and mandible; development of an experimental model. Dent Traumatol. 2009;25:78-83.
19. Sarahrudi K, Mousavi M, Grossschmidt K, Sela N, König F, Vécsei $\mathrm{V}$, Aharinejad S. Combination of anorganic bovine-derived hydroxyapatite with binding peptide does not enhance bone healing in a critical-size defect in a rabbit model. J Orthop Res. 2008;26:759-63.

\section{Correspondence:}

José Eduardo Ferreira Manso

Universidade Federal do Rio de Janeiro

Av. Professor Rodolpho Paulo Rocco, 225

21941-913 Rio de Janeiro - RJ Brasil

Tel.: (55 21)2562-2220 Ramal 2220

Conflict of interest: none

Financial source: Fundação Carlos Chagas Filho de Amparo à Pesquisa do Estado do Rio de Janeiro - FAPERJ and Conselho Nacional de Desenvolvimento Científico e Tecnológico - CNPq

${ }^{1}$ Research performed at the Experimental Surgical Center and Postgraduate Program, Department of Surgery, Faculty of Medicine, Federal University of Rio de Janeiro (UFRJ), Brazil.

Presented at the XII National Congress on Experimental Surgery of the Brazilian Society for Development of Research in Surgery-SOBRADPEC, 2011 October 26-29 Ribeirao Preto-SP, Brazil. 